\title{
Assuring Effectiveness in Consumer-Oriented Traceability; Suggestions for Food Label Design
}

\author{
Angelo Corallo (D), Maria Elena Latino*(D), Marta Menegoli (D) and Roberta Pizzi \\ Innovation Engineering Department, University of Salento, 73100 Lecce, Italy; angelo.corallo@unisalento.it (A.C.); \\ marta.menegoli@unisalento.it (M.M.); roberta.pizzi@unisalento.it (R.P.) \\ * Correspondence: mariaelena.latino@unisalento.it
}

check for

updates

Citation: Corallo, A.; Latino, M.E.; Menegoli, M.; Pizzi, R. Assuring Effectiveness in Consumer-Oriented Traceability; Suggestions for Food Label Design. Agronomy 2021, 11, 613. https:/ / doi.org/10.3390/agronomy 11040613

Academic Editors: Rosa Maria Fanelli, Santiago Pereira-Lorenzo and Ana María Ramos Cabrer

Received: 22 January 2021

Accepted: 18 March 2021

Published: 24 March 2021

Publisher's Note: MDPI stays neutral with regard to jurisdictional claims in published maps and institutional affiliations.

Copyright: (c) 2021 by the authors. Licensee MDPI, Basel, Switzerland. This article is an open access article distributed under the terms and conditions of the Creative Commons Attribution (CC BY) license (https:/ / creativecommons.org/licenses/by/ $4.0 /)$.

\begin{abstract}
Traceability is an important tool used by food companies and regulators in assuring food safety and quality, especially when consumers' needs for food information transparency are the driver. Consumers consult the label to find out more details about a food product and, although many factors influence their perceptions and purchasing acts, the label remains the primary means of communicating food information affecting consumer choice. Therefore, it represents the final step in a consumer-oriented traceability path. It follows that a suitable label design can improve the food traceability process and reduce the information asymmetry between producer and consumer. According to this view, this paper aimed to identify suggestions about food label design, in order to create a support framework for food companies in food information communication increasing label readability, customer satisfaction, and the effectiveness of traceability. A systematic literature review method with content analysis was chosen to conduct the study. Eleven specific suggestions from food labeling design theories were recognized. The novelty of the present study consisted in mapping the food label design field, synthesizing the current knowledge, and providing a support framework for food companies that would increase the readability of food labeling and enhance customer satisfaction through a well-proposed food information communication in line with the "farm to fork" strategy.
\end{abstract}

Keywords: traceability information; food labeling; food label design; food label theory; package; food choice

\section{Introduction}

Currently, consumer awareness of information about food quality and safety is driving research towards developing various methodologies to support food companies in implementing transparency-based procedures such as certifications, traceability, and audit [1]. In particular, traceability and transparency in the food industry and agribusiness address both companies and marketing needs, such as the optimization of logistical activities and business processes, the improvement of market efficiency, the enhancement of information sharing among supply chain actors from farm to fork, and the improvement of food quality communication [2]. The labels on packaging play a role in this by including and communicating food information. As a key issue of the marketing mix [3], packaging represents for consumers the way to learn product information and can be used by food companies to stimulate sales [4]. Indeed, labeling, as part of food packaging, is the best means to give proper product information to consumers [5-8], responding to their expressed and implicit cognitive needs $[5,9,10]$.

The average consumer makes many food decisions each day, most of them unconsciously [9], influenced by cognitive and emotional issues [10]. Thus, several factors influence people's food choices including health, cost, convenience, taste [11,12], and personal and environmental safety [13].

Communicating information to consumers in a way that is able to satisfy these needs is both a social and a business goal. Since the label represents the real interface between 
consumers and food companies, in the absence of a face-to-face encounter $[8,14]$, the most important challenge is to make a food label sufficiently informative but not misleading.

Deceptive communication, deriving for instance from fraudulent claims, leads consumers to make unhealthy and unsafe choices, undermines fair commercial practices and trust in food markets, and jeopardizes the sustainability of the food system [15]. The sustainability of the food system is a priority of the 2019-2024 European Union (EU) strategy. The EU leverages on its "from farm to fork" action in order to ensure a fair economic return in the supply chain and ensure that Europeans have access to healthy, affordable, and sustainable food. Particularly, during the Covid-19 pandemic, the focus on individuals healthcare and well-being have been strengthened. In such a challenging time, keeping people healthy and safe is critical while maintaining a high level of food safety and consumer trust. Against this backdrop of heightened uncertainty, up-to-date and reliable information about food is more important than ever [16].

Governments across the world make available guidelines for food labels design in order to provide consumers with food information, helping them to make conscious food choices in a more sustainable way. For instance, in the USA, the Food and Drug Administration (FDA) and United States Department of Agriculture (USDA) declare several elements of food labeling as mandatory (statement of identity, net contents, nutrition facts panel, ingredient statement, statement/warning on allergens, country of origin, name, and place of business).

Food labeling standards also originate from non-government organizations (Codex Alimentarius; Food and Agriculture Organization of the United Nations), defining rules for pre-packaged foods, nutrition and health claims, and nutrition labels. However, food packaging shows several types of information, not all mandatory by regulation. Indeed, food labels also include marketing information (i.e., advertisements, claims). Moreover, an increasing number of ethical and external qualities labels, such as eco, sustainability, fairtrade, carbon footprints, organic, are often packaged for commercial purposes. These labels fall into the "certification labels" category [8,17-22]. Certainly, food companies respect the labeling regulations but add other information in order to reach consumers. Indeed, it is also demonstrated that the claims in labels are able to affect and change consumers' food choices [23].

The huge range of information, some of which is really not necessary, risks confusing consumers in their food choice decision-making process [24,25]. Consumers' ability to correctly understand the information shown on product labels can be essential for health and safety or simply to make an informed choice, respecting personal principles and values $[26,27]$. The difficulties in the understandability of food information on labels are essentially related to food label perception, intelligibility, and interpretation, and several factors could affect these: (i) Choice conditions at the time of purchase [28]; (ii) product name and its unintended semantic meaning [29-31]; (iii) proper label readability [32]; (iv) color combinations related to food healthiness perception [33] or even psychological and socio-cultural associations and meanings of colors in a cross-cultural perspective [34]; (v) context and individual conditions at the time of purchasing [28,35]; (vi) role played by taste [36]; (vii) bias against certain product categories such as Genetically Modified Organisms (GMO) [37,38]; (viii) difficulty related to storage conditions and consumption [39]; (ix) role played by emotions in reaction to a product or a situation [35]; (x) incorrect or partial content perception [40,41]; or (xi) product comparison difficult due to several formats of labels [42].

Several studies have focused on the analysis of food label theories or design. The majority explore the issue from the consumers' perspective, others focus on nutrition and health, daily foodstuffs and meal effects on health, the food industry and related products, impacts on the market and society, and child nutrition, as emerged from a previous study by the authors. Moreover, an interesting part of the literature focused on applying eye-tracking methods to detect the consumer's response to different food label designs [43-47]. Nevertheless, to the best of our knowledge, no suggestions for labeling 
design have been defined. The novelty and the purpose of the present study consisted in mapping the food label design field, synthesizing the current knowledge, and providing a support framework for food companies that would increase readability and customer satisfaction through a well-proposed food information communication aligned with the "farm to fork" strategy. A systematic literature review method with content analysis was chosen to achieve this purpose.

The results of the present study contribute to identifying best practices in food label design. A list of suggestions on label design could benefit: (i) Food companies to improve their products and labels, (ii) governments to understand how social policies are acknowledged by consumers and how to create new better fitted policies, (iii) practitioners studying the field for the first time facilitating bibliographical referencing and providing an overview of the topic, and (iv) researchers by the identification of new possible research routes.

\section{Materials and Methods}

A review methodology is strategic to systematically analyze a body of knowledge [48]. According this principle, we chose to utilize a systematic literature review methodology in order to establish the boundaries of current knowledge This kind of review, applying a specific protocol, aims to search and critically analyze the previous literature in a specific field [49]. It is widely recognized that systematic literature reviews allow for the enhancement of the quality of review methodology and related results through the transparency and replicability of the protocol [48,50-52] and, improve the generalizability of the findings allowing the systematic synthesis and analysis of the knowledge that compose a given domain [53]. Particularly, among the several kinds of systematic literature review proposed by Paul and Criado [54], we chose to apply the domain-based review and, according to the Prisma guidelines [55], we proposed a review protocol composed of 3 steps discussed below: Search scheme and sample definition, quality assessment, data analysis (Figure 1).

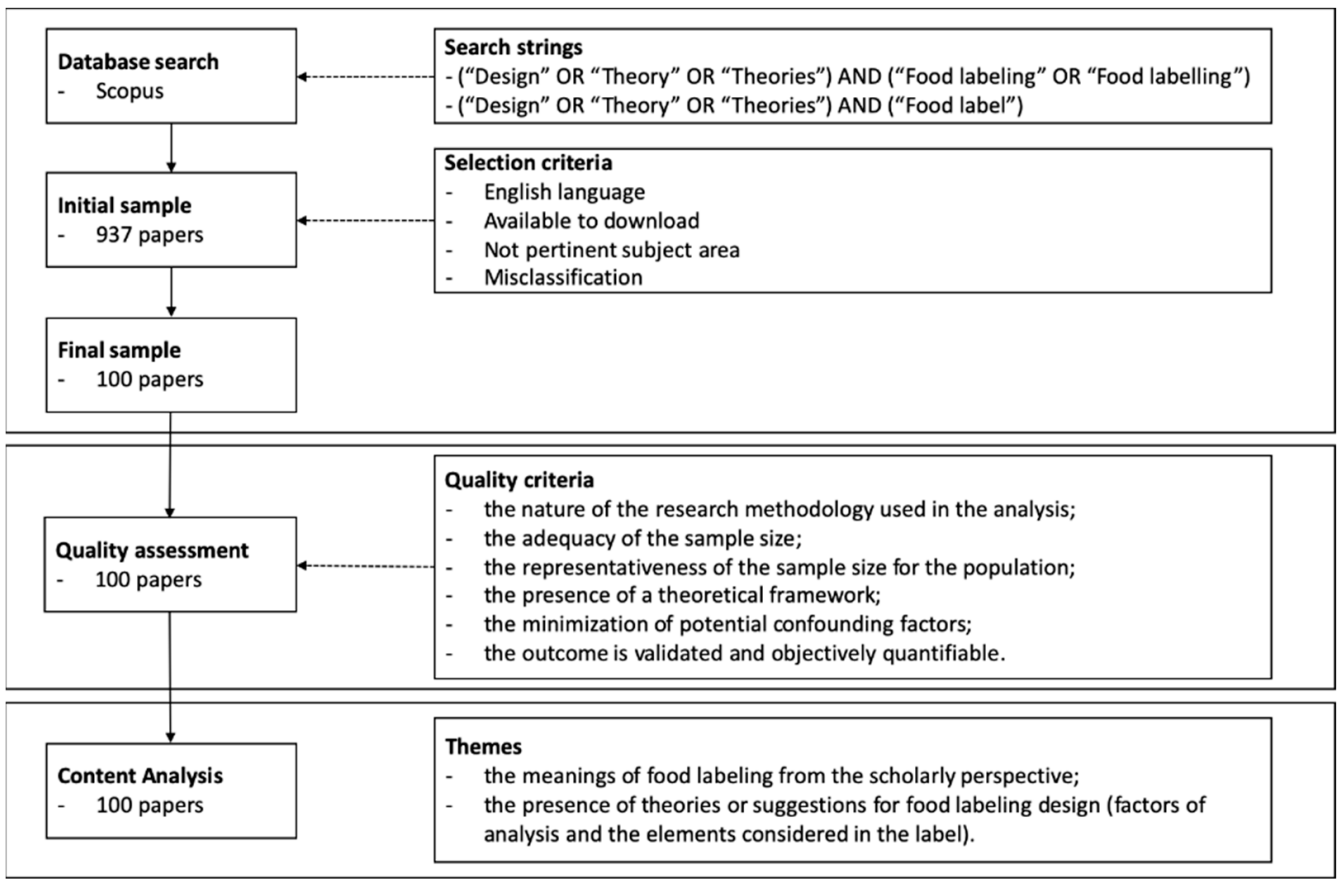

Figure 1. Research methodology in domain-based systematic literature review.

\subsection{Search Scheme and Sample Definition}

Several authors have identified the need to propose a focused research question or topic to obtain focused results from a literature review [56,57]. Keyword searching represents the method commonly used to identify relevant literature [58], and the use of Boolean operators allows the search to be refined [58]. A valid online article/bibliographic 
database was identified, as suggested by [59]. Using keywords representative of the inquired scenario [57], the following combinations were defined:

- (“Design" OR “Theory" OR “Theories") AND ("Food labeling” OR “Food labelling"); - ("Design" OR “Theory" OR “Theories") AND ("Food label").

OR and AND Boolean operators were chosen because they are able to, respectively, retrieve citations that contain one of the specified terms and retrieve a set of citations in which each citation contains all search terms, which could appear in any order [59].

On the one hand, the proposed scheme was adequately narrowed down to our research focus, and on the other hand, it did not limit the research to specific kinds of label (e.g., organic, fair trade, GMO) or specific elements that could be found in a label (e.g., logo, claim, advice).

The Scopus (www.scopus.com (accessed on 24 March 2021)) database was chosen to provide works with academic relevance according to our domain [60]. It was considered as a good source [61] and more comprehensive than others [62]. The search in Scopus was conducted in December 2020, in the "Article title, Abstract, Keywords" section, and no temporal limitation was set. An initial sample of 937 papers was identified. According to [63], the initial sample was restricted on the basis of the following criteria: (i) Limiting to research article or paper, available to download, in the English language, (ii) excluding works relating to a subject area deemed not pertinent with the present study and recognized misclassification. The final sample was composed of 100 papers.

\subsection{Quality Assessment}

Quality assessment is a step in systematic literature review proposed to evaluate, using specific criteria, the quality score of the papers sampled [64]. The sample was assessed by applying the Critical Appraisal Checklist Instrument proposed by the Joanna Briggs Institute (JBI) [65]. The protocol is composed of six criteria: (i) The nature of the research methodology used in the analysis; (ii) the adequacy of the sample size; (iii) the representativeness of the sample size for the population; (iv) the presence of a theoretical framework; (v) the minimization of potential confounding factors; (vi) the outcome being validated and objectively quantifiable. For each criterion, a quality rating was assigned (low, medium, high). Finally, a study was considered as "high quality" if it rated "high" on three or more criteria; "medium quality," if it received two "high" or one "high" and two "medium" ratings; the remaining studies were classified as "low quality" [63]. The quality assessment of the papers sampled (Figure 2) resulted in a medium-high rating: 24 out of 100 studies identified were ranked as high quality, 42 out of 100 as medium quality, and 34 out of 100 as low quality.

\subsection{Data Analysis}

Content analysis was carried out on the selected sample of papers, in order to investigate: (i) The meanings of food labeling from the scholarly perspective; (ii) the presence of theories or suggestions for food labeling design, considering the factors of analysis and the elements considered in the label. This method was useful in consumer research, and also in its applications in the field of package design $[18,66]$. 


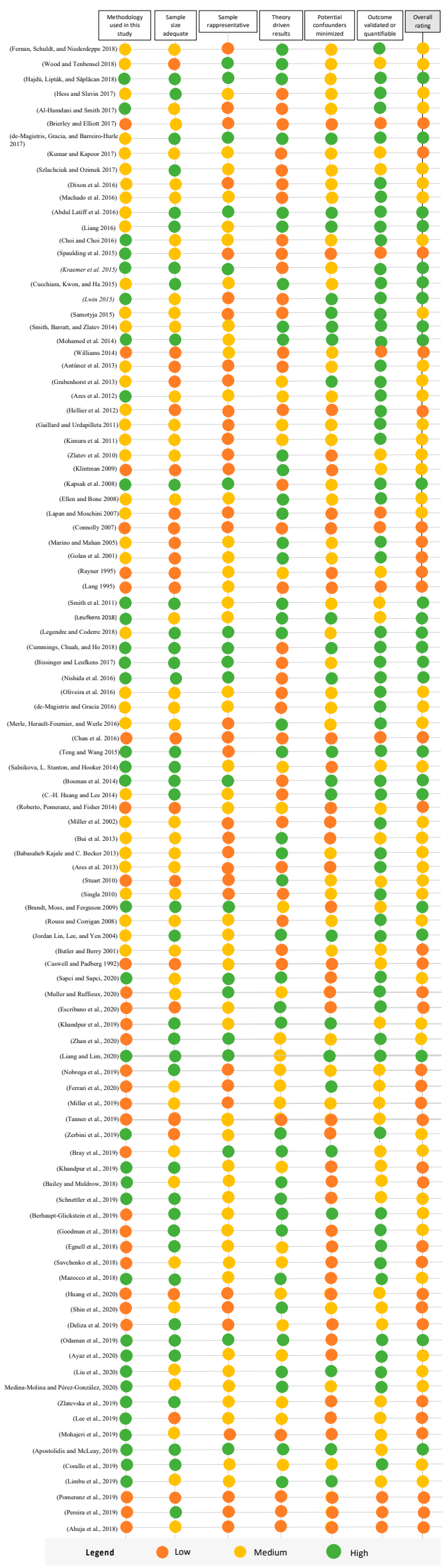

Figure 2. Quality assessment of sample. 


\section{Results}

Labeling is not yet uniquely defined. Some authors report a specific definition, others discuss the label concept in generic way. Several definitions of labeling are used in different fields: Academic, regulation, and International Organization for Standardization (ISO). The presence of papers in which the authors did not propose any definition of labeling was also found: About $45 \%$ of the sample did not explain the label meaning, but conducted an analysis of it (see Section 1 of Table 1).

Table 1. Results from content analysis.

\begin{tabular}{|c|c|c|}
\hline \multicolumn{3}{|c|}{ Section 1: Label Definition } \\
\hline Specific Def. & $\begin{array}{l}\text { Academic } \\
\text { Regulation } \\
\text { ISO }\end{array}$ & $\begin{array}{c}{[8,41,44,45,67-102]} \\
{[76,86,103-108]} \\
{[78]}\end{array}$ \\
\hline \multicolumn{2}{|c|}{ Generic Def. } & {$[5,6,26,47,109-114]$} \\
\hline \multicolumn{2}{|c|}{ No emerging meaning } & {$[7,20,29-31,37,38,46,115-153]$} \\
\hline \multicolumn{3}{|c|}{ Section 2: Label Definition Points of View } \\
\hline \multicolumn{2}{|c|}{ Generic point of view } & $\begin{array}{c}5-8,29-31,44,45,67,70,72,76,79,81-83,87- \\
90,92,94,95,97,101,102,104,106- \\
108,112,113,117,121,123-126,129-131]\end{array}$ \\
\hline Content & $\begin{array}{l}\text { Geographical label } \\
\text { Shelf life label } \\
\text { Allergy label } \\
\text { Nutrition label }\end{array}$ & $\begin{array}{c}{[78,85,106]} \\
{[103]} \\
{[109]} \\
{[28,72,76,81,87,115,129,154]} \\
\end{array}$ \\
\hline \multicolumn{2}{|c|}{ Position } & {$[43,49,69,70,75,92,94,101]$} \\
\hline Product & $\begin{array}{c}\text { Genetically modified food } \\
\text { Organic } \\
\text { Baby food }\end{array}$ & $\begin{array}{c}{[39,40,112]} \\
{[74,86,152]} \\
{[110]}\end{array}$ \\
\hline & & {$[20,78]$} \\
\hline
\end{tabular}

\section{Section 3: Focus of the Studies}

\section{Label Design Theory}

Studies that propose a theory to better design a label

Consumer perception of food according to the label

Studies that analyze consumer perception about food after the consumer has consulted the food label

$[43,48,70,85,88,89,98,112,119,135,137,139,140$, $144,150,151]$

\section{$[8,70,72-$}

Consumer behavior about food according to the label

Studies that analyze consumer behavior about food after the consumer has consulted the food label

$74,76,78,82,85,88,91,96,103,105,106,110,112,116$ $119,124,125,132,133,137,141,144,146,147]$

\section{Analysis about nutritional level of food}

Studies that analyze the perception of food nutritional level after label consultation

Consumer preference about label styles

Studies that analyze consumer preference about several styles of labels

$[26,71,75,91,92,94,95,115,123,140,143,148-$ $151,153]$

$[47,84,87,91,92,98,110,118,134,135,142,143]$

\section{Label understandability}

Studies that analyze the level of understandability of several labels perceived by the final consumer

\section{Other}

Studies that treat issues of label design not considered relevant for our analysis
$[81,94,96,105,131,136,150]$

$[5,20,29-31,37,38,67,68,77,79,81,99-$ $102,107,113,122,126,128,129,152]$

Analyzing each definition, they were characterized according to several points of view: Content, position, product, process, or with any specific connotation (generic point of view), as shown in Section 2 of Table 1. 
Some of the results deserve to be highlighted. Only $49 \%$ of the studies considered the labels from a specific point of view, despite labels or the labeling process being the main subject of $72 \%$ of the studies. Some authors [76,86,103-108] reported a specific definition coming from the regulation field, treating the label from a content point of view: [103] writes about shelf-life labeling that is regulated by the EU Commission in order to protect consumers' interests in a product's shelf-life, considered a guarantee of good quality and safety; [105] reports that a geographical indication label is certified and regulated, as foreseen by the EU Regulation 1151/2012 that establishes the means to report a "product specification"; [86] considers "nutrition labeling as a policy tool (mandatory information) or as a voluntary marketing communication" and refers to a specific definition coming from regulation, as foreseen by the Codex Alimentarius (CAC/GL 2-1985, Rev. 1-1993).

Only two studies $[20,78]$ reported on a label definition from a process point of view, writing both about eco labeling and the related aspect of environmental sustainability in the production processes required.

Moreover, $80 \%$ of specific label definition with a position point of view came from the academic field. Indeed, all studies took into account the front of package (FOP) label with different scopes: (i) Increasing the perceived amount of nutrients through the usage of claims [41,93]; (ii) developing a collaborative decision-making processes [68]; (iii) evaluating the importance of colors and text description in order to increase its understanding $[70,92,101]$; and (iv) improving label understanding through the usage of graphical elements rather than textual elements [74].

Thus, content analysis was focused on the recognition of good suggestions in food label design, and the focus of the studies was analyzed leading to the recognition of 8 categories of topic (Section 3 of Table 1 ).

Even if only some authors proposed a theory for label design, good suggestions in label design arose from the other papers. Then, papers were analyzed looking for the factors and label elements considered in the studies.

In particular, only [89] treated label design considering the dimension of the elements in a label, more than the contents, as factors of analysis. The author studied the space dedicated to several contents on food labels with the aim to evaluate the right trade-off between mandatory and voluntary information shown on labels, in order to ensure, at the same time, a healthy food choice and a conscious purchase decision by the consumer.

Some papers $[7,46,115,122]$ considered as the object of analysis both the contents and graphical elements with particular attention to: The structure of the functional claims [121]; nutrition table, color and graphical formats [114]; health claims, diet and low-calories claims, ingredient list, nutrition table, storage condition recommendation, calorie information, brand and product name, background and graphical formats [7]; health claims, brand and product name, and background [44]. The results were varied. From Kapsak et al. (2008) emerged the overall difficulty of consumers to comprehend current food labels, which requires simpler language regarding food, avoiding science- and/or disease-focused commentary. The major finding was that claims (i.e., "calcium builds strong bones") perform "successfully in communicating to consumers the healthy value of a food product, as well as its quality and safety" [121]. Marino and Mahan (2005) suggested considering matching the visual and cognitive processing requirements of decision-making in order to better support the decision performance in the nutrition labels context. Rayner $(1995,30)$ stated that a correct label design "is about the careful integration of words, typography, images and visual devices to render complex information sets and procedures easier to understand." More attention should be given to the density of information reported on a food label [44], indeed consumer attention is indirectly proportional to increasing information density. Oliveira et al. $(2016,166)$ suggest that "health claims should be written as concise as possible to assure that consumers fully process them $[\ldots]^{\prime \prime}$.

Some of the analyzed papers reported suggestions useful to better design a food label. First of all, it should be taken into account that label messages are judged and evaluated by the consumer, simultaneously with the rest of the package [8]. Thus, wording and 
graphical contents should both be considered important. An underlying assumption is that the information present on a food label should be user-friendly, in order to facilitate the understanding of food details by the consumer. From the point of view of the textual content, food information should be communicated through ordered, clear, simple, concise, and non-technical expressions [72,82,111,129], with a larger readable font size being better $[105,110,111]$ in order to enhance subjective hedonic expectations [67]. From the point of view of the graphical element, several authors $[30,46,69,74,80,85,93,109,126,141-143,150]$ contend that images, pictographs, and standardized synthesis graphical systems are more powerful than textual contents in terms of attractiveness and transmission of messages. Particularly, standardized synthesis graphical systems (like the traffic light system or choices checkmark symbol) could increase the perception of product healthiness, guiding the consumer during the selection and purchase processes $[80,126]$. Regarding warning labels, the triangular symbol with a white background and the signal word, "High in" is more visible to consumers, capturing their attention and informing their food purchases better than the signal words "A lot of" and the octagonal symbol [91,92]. Moreover, more attention could be given to the choice of elements like background, wording style, and picture. Light blue-colored food packages increase not only the attractiveness of the food products but also increase their consumption [69]. Increasing the contrast between colors improves the readability of the food label [104]. Indeed, [45] also debated that "the great majority of consumers fixate their gaze on four key areas (image, brand, ingredients, and nutritional information) for the food labels." Some of these elements occupy a front of package area, giving the food label a double function: Informing the consumer of the food contents and acting as a poster hoarding $[79,82]$. Taking into consideration that consumers value the public labels (regulated by EU [155]) more highly than private ones [117], several are the information elements considered valuable and inalienable by the consumer.

The information already present on food label that is most requested and valued by consumers are: Designation of origin followed by the organic logo or country of origin (COO) label [78,85,113,118], the nutritional panel and warnings [113,118,139,150] (better if calculated per $100 \mathrm{~g}$ of product [75]), the expiry date or the date of the maximum shelf life [118,132] (with most preference for the wording "best before" [103]), and the price [112]. It is interesting to note that other information was reported as impactful for consumers. The usage of claims, better if short [130], could increase the perception of food quality, healthiness, trust, and influence the food choice $[43,70,102,107,139,144]$. In the case of certified food products (i.e., organic food, GMO, Protected Geographical Indication, Protected Designation of Origin), adding details on the authentication source or food quality can enhance consumers' awareness of food and the related authentication mechanisms $[39,74,89,106]$. Regarding food information not reported on a label yet, it should go beyond the basic needs of consumers and reflect consumers' lifestyles and philosophies, increasing the product appeal $[79,98,135]$. New labels include: The eco label [78], fair-trade (more valued than the organic label [83]), and transformation product mode [85].

Summarizing, from the previous content analysis, eleven suggestions for food label design are recognized:

(i) Use simpler language avoiding technical commentaries [72,82,111,129];

(ii) Avoid a high density of information, integration of words, typography, and images $[7,44]$ in order to match visual and cognitive processing requirements [114];

(iii) Use large size font in order to enhance subjective hedonic expectations [10,105,110,111];

(iv) Use a light blue color for food packaging to increase attractiveness of the product and indirectly increase food consumption [69];

(v) Increase the contrast between the color of text and image [104];

(vi) Report nutritional panel with measures calculated per $100 \mathrm{~g}$ of product [75];

(vii) Report maximum shelf life [118] with most preference to the wording "best before" [103] or "expires on" instead of "sell by" [132];

(viii) Use claims with a short format [130]; 
(ix) Use nutritional warnings [138,149] with triangular symbol, white background and "high in" text [91,92];

(x) Add details about the source and mechanism of authentication with regard to certified food product $[39,74,89,106]$;

(xi) Encourage the use of labels that respond to new consumers' perceptions and lifestyles such as the eco label [78], fair-trade (more valued than the organic label [83]), and transformation product mode [85].

The importance of a good food label design is evident both (i) to assure readability and understandability for consumers in order to make conscious food choices based on accurate food information, and (ii) to increase food companies' ability to showcase through a tradeoff between mandatory and voluntary food information [89]. Furthermore, authors suggest assisting consumers in nutritional education, through suitable policies to guide people in the correct interpretation of food labels, starting from school educational level $[5,28,129]$.

\section{Discussion}

The analysis conducted showed that no univocal and shared meaning about food labeling exists, since numerous definitions have been proposed.

In particular, some authors have examined the meaning of food labeling from a well-rounded perspective. Others conceive food label referring to several points of view. Generally, food labeling was discussed as a tool able to represent food product information, but, in some cases, it could specifically refer to the contents in the label, to the position of the elements in the label, to a specific product category or to a specific production process.

Although all the papers analyzed supply suggestions for food label design, only $13[6,7,46,49,90,99,115,117,121,122,134,135,142]$ reported suitable theories.

In all the remaining cases, the focus of the studies ranged from consumer food perception according to label understandability, passing through consumers' behaviors in referring to food labels, analysis about the nutritional level of food, consumers' preference about label styles, and the analysis of consumers' needs relating to labels. The papers in the sample were focused on several factors of analysis: Element position, content, dimension and graphical elements, and considered the following label elements: Claims; ingredients list; table; recommendation; product information; and graphical details. Food labeling design seems to be embracing a scientific panorama with different scopes, through different analysis, based on different factors, considering different label elements. In this regard, eleven were recognized suggestions for food label design, with eight suggestions referring to content issues ( $\mathrm{i}$, ii, vi, vii, viii, ix, $\mathrm{x}, \mathrm{xi}$ ), two suggestions referring to graphical issues (iv, v), and only one suggestion referring to a wording issue (iii). All the recognized suggestions permit the design of food-directive labels [133] grading the whole food and each nutrient, both for healthy and unhealthy foods.

It is interesting to underline that these suggestions represent in most cases consumers' requirements or preferences (i, ii, iii, iv, v, viii, ix, xi), and in three cases issues already considered by governments to foster food safety and consumer health (vi, vii, $\mathrm{x}$ ).

Particularly, suggestion (vi) proposes the effectiveness of a nutritional panel with measures expressed per $100 \mathrm{~g}$ of the product. In the European Community, regulation $1169 / 2011$ represents the guidelines on food labeling, establishing that the nutritional elements must be expressed as mean values per $100 \mathrm{~g}$ (or $\mathrm{mL}$ ) of the product. Even if this is mandatory for EU countries, in other parts of the world regulations are different. For example, the USA regulation established that the nutritional value must be expressed using the concept of "serving size" which represents the amount of product considered sufficient to meet the nutritional needs of an average adult. The Food and Drugs Administration (FDA) established that the serving size could be expressed using several measurement units such as the ounce, gram, or cup. A cup is equal to $240 \mathrm{~mL}$ and the conversion into grams depends on the type of product. As debated by [75], in Brazilian consumers, this generates difficulty in understanding the right amount of food to eat to maintain health. To overcome this issue, authors recommend the inclusion of nutritional information per $100 \mathrm{~g}$. 
Suggestion (vii) referring to the shelf life is reflected in the legislation. The EU regulation 1169/2011 established that the expiration date must be introduced by the labels as "best before" or "use by." Other terms are considered illegitimate. Even though [103] discovered that European consumers prefer the label "best before" underlining the effectiveness of the EU regulation, the results found by [132] showed "expires on" is preferred over "sell by" among US consumers. Indeed, not all countries have the stringent conditions proposed by the EU in the regulation about expiration date. In the USA, there are no standardized descriptions for open dating [156]: "Sell by," "use by," and "best if used by" are some of the commonly used labels [157].

Finally, suggestion ( $x$ ) refers to the importance of adding details about the authentication mechanism for certified food products. The EU Regulation 2018/848, which entered into force on 1 January 2021, acknowledges this need, and requires companies to show on the label of organic food products two identification numbers to univocally identify the product and the certification body.

These suggestions, even if they are already contained within the regulations in some countries, could be useful for food companies that operate in less regulated markets and/or for governments to obtain feedback on the effectiveness of the established regulations.

Indeed, the existing literature demonstrates that poor dietary choices are partly dependent on food marketing $[158,159]$. Food companies can adopt several strategies, also in combination, to engage consumers [160]: Information on food labels (such as claims, logo, advice); marketing strategies (such as product appearance in television shows, movies, games, magazines); viral marketing or viral advertising (uses existing social networks to promote a product on the net through a buzz strategy, such as "word of mouth"); sales promotions (such as coupons, mailings); and co-branding strategies (for instance different corporates together create a new product).

Considering that, for instance, over half of all food dollars in the USA are spent on food consumed at home [161], a trend that has probably grown during the Covid-19 pandemic, the marketing strategies applied to food labels may also influence consumption patterns at the time of the purchasing act, having an important impact on health and, for instance, obesity outcomes [162]. The global debate on food marketing's role in public health and awareness has also migrated to policy making. For instance, Michelle Obama, the ex-First Lady of the USA, communicated actions "to revise the way food labels carried nutritionrelated information in her country [ ... ], as the only way people could make 'informed choices' was 'by having clear, accurate information'" [77]. Understanding what kind of information is presented on food labels is important, especially when a bad evaluation of food information can cause disease. Practitioners need to be conscious of the marketing strategies and at the same time governments must consider the potential of the food label to influence and proceed to act policies able to protect consumers from misleading food information.

\section{Conclusions}

Referring to the study purpose declared in the Introduction section, this study mapped the food label design field synthesizing the current academic knowledge about:

- Food label definitions and the related points of view;

- The aims of current food label studies;

- The factors considered in food label design analysis.

Even if no univocal and shared meaning about food labeling exists, and generally the food labeling was conceived as a tool to represent food product information, it could specifically refer to the provided contents, to the position of the elements, to a specific product category, or to a specific process in production.

The focuses of the studies range from food label design theories, passing through consumers' food perception according to label understandability, consumers' behaviors in referring to food labels, analysis of the nutritional level of food, consumers' preference about label styles, and the analysis of consumers' needs from the label. The analyses of 
food label design conducted in the selected papers were focused on several factors: Elements position, content, dimension and graphical elements, and considered the following label elements: Claims; ingredient list; table; recommendation; product information; and graphical details. Starting from these evidences and in order to achieve the purpose of the study, eleven suggestions in food label design are recognized. These represent a support framework for food companies that would increase label readability and consumers' satisfaction, improving the communication process around food, and reducing the information asymmetry between food company and consumer [163].

Indeed, food companies could find eight useful suggestions to better manage contents in food labels (i, ii, vi, vii, viii, ix, x, xi), two suggestion referring to how to improve the graphical design of the label (iv, v), and a wording suggestion useful to avoid misunderstanding among consumers (iii).

The novelty of the present study consists in a systematization of the previous knowledge about food label design into eleven suggestions. It is hoped that the results of the study will be interesting for: Those studying the field for the first time, facilitating bibliographical referencing and providing an overview about the topic; supporting food companies in food label design in order to increase label readability and customers' satisfaction; supporting researchers in the identification of new possible research routes; helping governments to understand how social policies are received by consumers and how to create new policies.

Concluding, it is interesting to underline that the studies considered treated the label and the label design from a traditional view (a physical label on primary packaging). No study on the design of a virtual label was found, underlining a gap in the literature about virtual labeling design in the food industry. This evidence could be attributed to a fundamental lack of awareness as to their purpose (i.e., the usage of $Q R$ codes to extend the label contents is not viewed by consumers as adding value), which represents a failure of marketing efforts to inform consumers [90]. Further research studies could investigate consumers' awareness about virtual labeling in order to evaluate if food companies could leverage the same best practice in food label design.

Author Contributions: Conceptualization, M.E.L. and M.M.; methodology, M.E.L. and M.M.; validation, A.C.; formal analysis and investigation, M.E.L. and M.M., R.P.; resources, A.C.; data curation, M.M. and R.P.; writing-original draft preparation, M.E.L., M.M., and R.P.; writing—review and editing, M.E.L. and M.M.; visualization, M.E.L. and M.M.; supervision, M.E.L. and A.C. All authors have read and agreed to the published version of the manuscript.

Funding: This research received no external funding.

Institutional Review Board Statement: Not applicable.

Informed Consent Statement: Not applicable.

Conflicts of Interest: The funders had no role in the design of the study; in the collection, analyses, or interpretation of data; in the writing of the manuscript; or in the decision to publish the results.

\section{References}

1. Amodio, M.L.; Chaudhry, M.M.A.; Colelli, G. Spectral and Hyperspectral Technologies as an Additional Tool to Increase Information on Quality and Origin of Horticultural Crops. Agronomy 2020, 10, 7. [CrossRef]

2. Trienekens, J.H.; Wognum, P.M.; Beulens, A.J.M.; van der Vorst, J.G.A.J. Transparency in Complex Dynamic Food Supply Chains. Adv. Eng. Inform. 2012, 26, 55-65. [CrossRef]

3. Plimmer, J. Augmenting and securing the consumer brand experience through smart and intelligent packaging for food, beverages and other fast-moving consumer goods. In Trends in Packaging of Food, Beverages and Other Fast-Moving Consumer Goods (FMCG); Elsevier: Amsterdam, The Netherlands, 2013; pp. 35-57. ISBN 978-0-85709-503-9.

4. Sen, M.K.C. Food Traceability and Consumer Awareness in Turkey: A Review Article. J. Anim. Vet. Adv. 2014, 13, 350-354.

5. Caswell, J.A.; Padberg, D.I. Toward a More Comprehensive Theory of Food Labels. Am. J. Agric. Econ. 1992, 74, 460. [CrossRef]

6. Lang, T. The Contradictions of Food Labelling Policy. Inf. Des. J. 1995, 8, 3-16. [CrossRef]

7. Rayner, M. Food Labelling and Information Design. Inf. Des. J. 1995, 8, 25-35. [CrossRef]

8. Tonkin, E.; Wilson, A.M.; Coveney, J.; Webb, T.; Meyer, S.B. Trust in and through Labelling-a Systematic Review and Critique. Br. Food J. 2015, 117, 318-338. [CrossRef] 
9. Chambers, L.; McCrickerd, K.; Yeomans, M.R. Optimising Foods for Satiety. Trends Food Sci. Technol. 2015, 41, 149-160. [CrossRef]

10. Grabenhorst, F.; Schulte, F.P.; Maderwald, S.; Brand, M. Food Labels Promote Healthy Choices by a Decision Bias in the Amygdala. NeuroImage 2013, 74, 152-163. [CrossRef] [PubMed]

11. Furst, T.; Connors, M.; Bisogni, C.A.; Sobal, J.; Falk, L.W. Food Choice: A Conceptual Model of the Process. Appetite 1996, 26, 247-266. [CrossRef]

12. Bublitz, M.G.; Peracchio, L.A.; Andreasen, A.R.; Kees, J.; Kidwell, B.; Miller, E.G.; Motley, C.M.; Peter, P.C.; Rajagopal, P.; Scott, M.L.; et al. Promoting Positive Change: Advancing the Food Well-Being Paradigm. J. Bus. Res. 2013, 66, 1211-1218. [CrossRef]

13. Bagozzi, R.P.; Warshaw, P.R. Trying to Consume. J. Consum. Res. 1990, 17, 127. [CrossRef]

14. Steptoe, A. Trends in Smoking, Diet, Physical Exercise, and Attitudes toward Health in European University Students from 13 Countries, 1990-2000. Prev. Med. 2002, 35, 97-104. [CrossRef] [PubMed]

15. Weirich, P. Labeling Genetically Modified Food: The Philosophical and Legal Debate; Oxford University Press: New York, NY, USA, 2007; ISBN 0-19-804382-1.

16. Carey, R.; Parker, C.; Scrinis, G. Capturing the Meaning of "Free Range": The Contest between Producers, Supermarkets and Consumers for the Higher Welfare Egg Label in Australia. J. Rural Stud. 2017, 54, 266-275. [CrossRef]

17. European Commission. Farm to Fork Strategy. Available online: https://ec.europa.eu/food/sites/food/files/safety/docs/f2f_ action-plan_2020_strategy-info_en.pdf (accessed on 23 February 2021).

18. Nakat, Z.; Bou-Mitri, C. COVID-19 and the Food Industry: Readiness Assessment. Food Control 2021, 121, 107661. [CrossRef] [PubMed]

19. Anagnostou, A.; Ingenbleek, P.T.M.; van Trijp, H.C.M. Sustainability Labelling as a Challenge to Legitimacy: Spillover Effects of Organic Fairtrade Coffee on Consumer Perceptions of Mainstream Products and Retailers. J. Consum. Mark. 2015, 32, $422-431$. [CrossRef]

20. Chrysochou, P.; Festila, A. A Content Analysis of Organic Product Package Designs. J. Consum. Mark. 2019, 36, 441-448. [CrossRef]

21. Klintman, M. Ambiguous Framings of Political Consumerism: Means or End, Product or Process Orientation? Int. J. Consum. Stud. 2006, 30, 427-438. [CrossRef]

22. Klintman, M. Participation in Green Consumer Policies: Deliberative Democracy under Wrong Conditions? J. Consum. Policy 2009, 32, 43-57. [CrossRef]

23. Koos, S. Varieties of Environmental Labelling, Market Structures, and Sustainable Consumption Across Europe: A Comparative Analysis of Organizational and Market Supply Determinants of Environmental-Labelled Goods. J. Consum. Policy 2011, 34, 127-151. [CrossRef]

24. Larceneux, F.; Benoit-Moreau, F.; Renaudin, V. Why Might Organic Labels Fail to Influence Consumer Choices? Marginal Labelling and Brand Equity Effects. J. Consum. Policy 2012, 35, 85-104. [CrossRef]

25. Vanclay, J.K.; Shortiss, J.; Aulsebrook, S.; Gillespie, A.M.; Howell, B.C.; Johanni, R.; Maher, M.J.; Mitchell, K.M.; Stewart, M.D.; Yates, J. Customer Response to Carbon Labelling of Groceries. J. Consum. Policy 2011, 34, 153-160. [CrossRef]

26. Charlebois, S.; Schwab, A.; Henn, R.; Huck, C.W. Food Fraud: An Exploratory Study for Measuring Consumer Perception towards Mislabeled Food Products and Influence on Self-Authentication Intentions. Trends Food Sci. Technol. 2016, 50, 211-218. [CrossRef]

27. Fitzgerald, M.P.; Donovan, K.R.; Kees, J.; Kozup, J. How Confusion Impacts Product Labeling Perceptions. J. Consum. Mark. 2019, 36, 306-316. [CrossRef]

28. Lin, C.-T.J.; Lee, J.-Y.; Yen, S.T. Do Dietary Intakes Affect Search for Nutrient Information on Food Labels? Soc. Sci. Med. 2004, 59, 1955-1967. [CrossRef]

29. Moser, A.K. Buying Organic-Decision-Making Heuristics and Empirical Evidence from Germany. J. Consum. Mark. 2016, 33, 552-561. [CrossRef]

30. Sanjari, S.S.; Jahn, S.; Boztug, Y. Dual-Process Theory and Consumer Response to Front-of-Package Nutrition Label Formats. Nutr. Rev. 2017, 75, 871-882. [CrossRef]

31. Zlatev, J.; Smith, V.; van de Weijer, J.; Skydsgaard, K. Noun-Noun Compounds for Fictive Food Products: Experimenting in the Borderzone of Semantics and Pragmatics. J. Pragmat. 2010, 42, 2799-2813. [CrossRef]

32. Smith, V.; Barratt, D.; Zlatev, J. Unpacking Noun-Noun Compounds: Interpreting Novel and Conventional Foodnames in Isolation and on Food Labels. Cogn. Linguist. 2014, 25, 99-147. [CrossRef]

33. Gaillard, A.; Urdapilleta, I. Sorting Food Labels and Describing Properties of Categories: Stability of Results between and within Subjects. Psychol. Rep. 2011, 109, 187-207. [CrossRef]

34. Graham, D.J.; Mohr, G.S. When Zero Is Greater than One: Consumer Misinterpretations of Nutrition Labels. Health Psychol. 2014, 33, 1579-1587. [CrossRef] [PubMed]

35. Nyilasy, G.; Lei, J.; Nagpal, A.; Tan, J. Colour Correct: The Interactive Effects of Food Label Nutrition Colouring Schemes and Food Category Healthiness on Health Perceptions. Public Health Nutr. 2016, 19, 2122-2127. [CrossRef] [PubMed]

36. Aslam, M.M. Are You Selling the Right Colour? A Cross-cultural Review of Colour as a Marketing Cue. J. Mark. Commun. 2006, 12, 15-30. [CrossRef]

37. Spendrup, S.; Hunter, E.; Isgren, E. Exploring the Relationship between Nature Sounds, Connectedness to Nature, Mood and Willingness to Buy Sustainable Food: A Retail Field Experiment. Appetite 2016, 100, 133-141. [CrossRef] 
38. Brewer, J.M.; Shavit, A.Y.; Shepard, T.G.; Veldhuizen, M.G.; Parikh, R.; Marks, L.E. Identification of Gustatory-Olfactory Flavor Mixtures: Effects of Linguistic Labeling. Chem. Senses 2013, 38, 305-313. [CrossRef]

39. Ellen, P.S.; Bone, P.F. Stained by the Label? Stigma and the Case of Genetically Modified Foods. J. Public Policy Mark. 2008, 27, 69-82. [CrossRef]

40. Lapan, H.; Moschini, G. Grading, Minimum Quality Standards, and the Labeling of Genetically Modified Products. Am. J. Agric. Econ. 2007, 89, 769-783. [CrossRef]

41. Dickinson, A.; Wills, W.; Meah, A.; Short, F. Food Safety and Older People: The Kitchen Life Study. Br. J. Community Nurs. 2014, 19, 226-232. [CrossRef]

42. McCrory, C.; White, C.M.; Bowman, C.; Fenton, N.; Reid, J.L.; Hammond, D. Perceptions and Knowledge of Caffeinated Energy Drinks: Results of Focus Groups With Canadian Youth. J. Nutr. Educ. Behav. 2017, 49, 304-311.e6. [CrossRef]

43. Fernan, C.; Schuldt, J.P.; Niederdeppe, J. Health Halo Effects from Product Titles and Nutrient Content Claims in the Context of "Protein" Bars. Health Commun. 2018, 33, 1425-1433. [CrossRef] [PubMed]

44. Draper, A.K.; Adamson, A.J.; Clegg, S.; Malam, S.; Rigg, M.; Duncan, S. Front-of-Pack Nutrition Labelling: Are Multiple Formats a Problem for Consumers? Eur. J. Public Health 2013, 23, 517-521. [CrossRef]

45. Graham, D.J.; Orquin, J.L.; Visschers, V.H.M. Eye Tracking and Nutrition Label Use: A Review of the Literature and Recommendations for Label Enhancement. Food Policy 2012, 37, 378-382. [CrossRef]

46. Oliveira, D.; Machín, L.; Deliza, R.; Rosenthal, A.; Walter, E.H.; Giménez, A.; Ares, G. Consumers' Attention to Functional Food Labels: Insights from Eye-Tracking and Change Detection in a Case Study with Probiotic Milk. Lwt-Food Sci. Technol. 2016, 68, 160-167. [CrossRef]

47. Ares, G.; Giménez, A.; Bruzzone, F.; Vidal, L.; Antúnez, L.; Maiche, A. Consumer Visual Processing of Food Labels: Results from an Eye-Tracking Study: Visual Processing of Food Labels. J. Sens. Stud. 2013, 28, 138-153. [CrossRef]

48. Huang, J.; Peng, Y.; Wan, X. The Color-Flavor Incongruency Effect in Visual Search for Food Labels: An Eye-Tracking Study. Food Qual. Prefer. 2021, 88, 104078. [CrossRef]

49. Antúnez, L.; Vidal, L.; Sapolinski, A.; Giménez, A.; Maiche, A.; Ares, G. How Do Design Features Influence Consumer Attention When Looking for Nutritional Information on Food Labels? Results from an Eye-Tracking Study on Pan Bread Labels. Int. J. Food Sci. Nutr. 2013, 64, 515-527. [CrossRef] [PubMed]

50. Crossan, M.M.; Apaydin, M. A Multi-Dimensional Framework of Organizational Innovation: A Systematic Review of the Literature: A Framework of Organizational Innovation. J. Manag. Stud. 2010, 47, 1154-1191. [CrossRef]

51. Leonidou, E.; Christofi, M.; Vrontis, D.; Thrassou, A. An Integrative Framework of Stakeholder Engagement for Innovation Management and Entrepreneurship Development. J. Bus. Res. 2020, 119, 245-258. [CrossRef]

52. Christofi, M.; Leonidou, E.; Vrontis, D. Cause-Related Marketing, Product Innovation and Extraordinary Sustainable Leadership: The Root towards Sustainability. Glob. Bus. Econ. Rev. 2015, 17, 93. [CrossRef]

53. de Menezes, L.M.; Kelliher, C. Flexible Working and Performance: A Systematic Review of the Evidence for a Business Case: Flexible Working and Performance. Int. J. Manag. Rev. 2011, 13, 452-474. [CrossRef]

54. Tranfield, D.; Denyer, D.; Smart, P. Towards a Methodology for Developing Evidence-Informed Management Knowledge by Means of Systematic Review. Br. J. Manag. 2003, 14, 207-222. [CrossRef]

55. Wang, C.L.; Chugh, H. Entrepreneurial Learning: Past Research and Future Challenges: Advancing Entrepreneurial Learning Research. Int. J. Manag. Rev. 2014, 16, 24-61. [CrossRef]

56. Paul, J.; Criado, A.R. The Art of Writing Literature Review: What Do We Know and What Do We Need to Know? Int. Bus. Rev. 2020, 29, 101717. [CrossRef]

57. Moher, D.; Liberati, A.; Tetzlaff, J.; Altman, D.G. The PRISMA Group Preferred Reporting Items for Systematic Reviews and Meta-Analyses: The PRISMA Statement. PLoS Med. 2009, 6, e1000097. [CrossRef] [PubMed]

58. Cronin, P.; Ryan, F.; Coughlan, M. Undertaking a Literature Review: A Step-by-Step Approach. Br. J. Nurs. 2008, 17, 38-43. [CrossRef]

59. Newell, R.; Burnard, P. Vital Notes for Nurses: Research for Evidence-Based Practice; Wiley-Blackwell: Hoboken, NJ, USA, 2006; ISBN 1-4051-2562-4.

60. Ely, C.; Scott, I. Essential Study Skills for Nursing; Elsevier Health Sciences: New York, NY, USA, 2007; ISBN 0-7234-3371-2.

61. Fink, A. Conducting Research Literature Reviews: From the Internet to Paper; Sage Publications: Newbury Park, CA, USA, 2019; ISBN 1-5443-1848-0.

62. Bauer, J.M.; Reisch, L.A. Behavioural Insights and (Un)Healthy Dietary Choices: A Review of Current Evidence. J. Consum. Policy 2019, 42, 3-45. [CrossRef]

63. Mishra, D.K.; Sekhari, A.; Henry, S.; Ouzrout, Y. Traceability in Product Supply Chain: A Global Model. In Product Lifecycle Management for Digital Transformation of Industries; Harik, R., Rivest, L., Bernard, A., Eynard, B., Bouras, A., Eds.; Springer International Publishing: Cham, Switzerland, 2016; Volume 492, pp. 377-384. ISBN 978-3-319-54659-9.

64. Yong-Hak, J. The Definitive Resource for Global Research Web of Science Access Powerful Cited Reference Searching and Multidisciplinary Content; Thomson Reuters: Ann Arbor, MI, USA, 2019.

65. Bimbo, F.; Bonanno, A.; Nocella, G.; Viscecchia, R.; Nardone, G.; De Devitiis, B.; Carlucci, D. Consumers' Acceptance and Preferences for Nutrition-Modified and Functional Dairy Products: A Systematic Review. Appetite 2017, 113, 141-154. [CrossRef] [PubMed] 
66. Littell, J.H. Systematic Reviews in the Social Sciences: A Review. Evid. Policy A J. Res. Debate Pract. 2006, 2, 535-537. [CrossRef]

67. Institute, J.B. Comprehensive Systematic Review Module 3: The Systematic Review of Quantitative Evidence, Study Guide; Joanna Briggs Institute: Adelaide, Australia, 2011.

68. Elliott, C. Marketing Fun Foods: A Profile and Analysis of Supermarket Food Messages Targeted at Children. Can. Public Policy 2008, 34, 259-273. [CrossRef]

69. Wood, A.; Tenbensel, T. A Comparative Analysis of Drivers of Collaborative Governance in Front-of-Pack Food Labelling Policy Processes. J. Comp. Policy Anal. Res. Pract. 2018, 20, 404-419. [CrossRef]

70. Al-Hamdani, M.; Smith, S. Food Product Design: Emerging Evidence for Food Policy. Int. J. Food Sci. Nutr. 2017, 68, 131-137. [CrossRef]

71. Kumar, N.; Kapoor, S. Do Labels Influence Purchase Decisions of Food Products? Study of Young Consumers of an Emerging Market. Br. Food J. 2017, 119, 218-229. [CrossRef]

72. Machado, P.P.; Kraemer, M.V.; dos Kliemann, N.S.; Colussi, C.F.; Veiros, M.B.; da Proença, R.P.C. Serving Sizes and Energy Values on the Nutrition Labels of Regular and Diet/Light Processed and Ultra-Processed Dairy Products Sold in Brazil. Br. Food J. 2016, 118, 1579-1593. [CrossRef]

73. Latiff, Z.A.B.A.; Rezai, G.; Mohamed, Z.; Ayob, M.A. Food Labels' Impact Assessment on Consumer Purchasing Behavior in Malaysia. J. Food Prod. Mark. 2016, 22, 137-146. [CrossRef]

74. Liang, R.-D. Predicting Intentions to Purchase Organic Food: The Moderating Effects of Organic Food Prices. Br. Food J. 2016, 118, 183-199. [CrossRef]

75. Spaulding, C.J.; Mcneal, C.J.; Coppin, J.D.; Shimek, C.; Field, L.; Murano, P.S. Engaging Inner City Middle School Students in Development of an Energy Expenditure Food Label. J. Prev. Interv. Community 2015, 43, 123-134. [CrossRef]

76. dos Kraemer, M.V.S.; Machado, P.P.; Kliemann, N.; Chica, D.A.G.; da Proença, R.P.C. The Brazilian Population Consumes Larger Serving Sizes than Those Informed on Labels. Br. Food J. 2015, 117, 719-730. [CrossRef]

77. Lwin, M.O. Comparative Practices of Food Label Claims from US, EU and Selected Southeast Asian Countries. J. Consum. Mark. 2015, 32, 530-541. [CrossRef]

78. Newman, C.L.; Turri, A.M.; Howlett, E.; Stokes, A. Twenty Years of Country-of-Origin Food Labeling Research: A Review of the Literature and Implications for Food Marketing Systems. J. Macromark. 2014, 34, 505-519. [CrossRef]

79. Mohamed, Z.; Teng, P.K.; Rezai, G.; Sharifuddin, J. Malaysian Consumers' Willingness-to-Pay Toward Eco-Labeled Food Products in Klang Valley. J. Food Prod. Mark. 2014, 20, 63-74. [CrossRef]

80. Williams, W. Outward Facing: W\&R Jacob \& Co. Biscuit Labels, 1900-1939. J. Hist. Res. Mark. 2014, 6, 56-97. [CrossRef]

81. Ares, G.; Giménez, A.; Bruzzone, F.; Antúnez, L.; Sapolinski, A.; Vidal, L.; Maiche, A. Attentional Capture and Understanding of Nutrition Labelling: A Study BTased on Response Times. Int. J. Food Sci. Nutr. 2012, 63, 679-688. [CrossRef] [PubMed]

82. Golan, E.; Kuchler, F.; Mitchell, L.; Greene, C.; Jessup, A. Economics of Food Labeling. J. Consum. Policy 2001, $24,117-184$. [CrossRef]

83. Legendre, S.; Coderre, F. The Impact of Altruistic Attribution and Brand Equity in Food Label Campaigns. J. Prod. Brand Manag. 2018, 27, 634-646. [CrossRef]

84. Bissinger, K.; Leufkens, D. Ethical Food Labels in Consumer Preferences. Br. Food J. 2017, 119, 1801-1814. [CrossRef]

85. Merle, A.; Herault-Fournier, C.; Werle, C.O.C. The Effects of Indication of Local Geographical Origin on Food Perceptions. Rech. Appl. Mark. 2016, 31, 26-42. [CrossRef]

86. Teng, C.-C.; Wang, Y.-M. Decisional Factors Driving Organic Food Consumption: Generation of Consumer Purchase Intentions. Br. Food J. 2015, 117, 1066-1081. [CrossRef]

87. Salnikova, E.; Stanton, J.L.; Hooker, N. A Comparison of Front-of-Pack Nutrition Claims between the US and EU. Br. Food J. 2014, 116, 337-352. [CrossRef]

88. Bosman, M.J.; Van der Merwe, D.; Ellis, S.M.; Jerling, J.C.; Badham, J. South African Adult Metropolitan Consumers' Opinions and Use of Health Information on Food Labels. Br. Food J. 2014, 116, 30-43. [CrossRef]

89. Huang, C.-H.; Lee, C.-H. Consumer Willingness to Pay for Organic Fresh Milk in Taiwan. China Agric. Econ. Rev. 2014, 6, $198-211$. [CrossRef]

90. Stuart, S.A. The Relationship between Mandatory and Other Food Label Information. Br. Food J. 2010, 112, 21-31. [CrossRef]

91. Tanner, S.A.; McCarthy, M.B.; O’Reilly, S.J. Digital Labelling in the Retail Environment: A Domain-Specific Innovativeness Perspective. Int. J. Retail Disrtib. Manag. 2019, 47, 1336-1352. [CrossRef]

92. Khandpur, N.; Mais, L.A.; de Sato, P.M.; Martins, A.P.B.; Spinillo, C.G.; Rojas, C.F.U.; Garcia, M.T.; Jaime, P.C. Choosing a Front-of-Package Warning Label for Brazil: A Randomized, Controlled Comparison of Three Different Label Designs. Food Res. Int. 2019, 121, 854-861. [CrossRef]

93. Goodman, S.; Vanderlee, L.; Acton, R.; Mahamad, S.; Hammond, D. The Impact of Front-of-Package Label Design on Consumer Understanding of Nutrient Amounts. Nutrients 2018, 10, 1624. [CrossRef]

94. Egnell, M.; Talati, Z.; Hercberg, S.; Pettigrew, S.; Julia, C. Objective Understanding of Front-of-Package Nutrition Labels: An International Comparative Experimental Study across 12 Countries. Nutrients 2018, 10, 1542. [CrossRef] [PubMed]

95. Ayaz, A.; Dedebayraktar, D.; Inan-Eroglu, E.; Besler, H.T.; Buyuktuncer, Z. How Does Nutrition Education Contribute to the Consumers' Use and Attitudes towards Food Labels? Nutr. Food Sci. 2020, 10, 174. [CrossRef] 
96. Medina-Molina, C.; Pérez-González, B. Nutritional Labelling and Purchase Intention Interaction of Interpretative Food Labels with Consumers' Beliefs and Decisions. Br. Food J. 2020, 123, 754-770. [CrossRef]

97. Lee, T.H.; Fu, C.-J.; Chen, Y.Y. Trust Factors for Organic Foods: Consumer Buying Behavior. Br. Food J. 2019, $122,414-431$. [CrossRef]

98. Apostolidis, C.; McLeay, F. To Meat or Not to Meat? Comparing Empowered Meat Consumers' and Anti-Consumers' Preferences for Sustainability Labels. Food Qual. Prefer. 2019, 77, 109-122. [CrossRef]

99. Corallo, A.; Latino, M.E.; Pizzi, R.; Spennato, A.; Fortunato, L.; Menegoli, M. Human Factor in Smart Labelling: How Enhance Food Awareness in Consumers. In Proceedings of the 2019 6th International Conference on Frontiers of Industrial Engineering (ICFIE) 2019, London, UK, 10-12 September 2019; pp. 89-93.

100. Limbu, Y.B.; McKinley, C.; Gautam, R.K.; Ahirwar, A.K.; Dubey, P.; Jayachandran, C. Nutritional Knowledge, Attitude, and Use of Food Labels among Indian Adults with Multiple Chronic Conditions: A Moderated Mediation Model. Br. Food J. 2019, 121, 1480-1494. [CrossRef]

101. Pomeranz, J.L.; Wilde, P.; Mozaffarian, D.; Micha, R. Mandating Front-of-Package Food Labels in the U.S.-What Are the First Amendment Obstacles? Food Policy 2019, 86, 101722. [CrossRef]

102. Pereira, R.C.; de Angelis-Pereira, M.C.; Carneiro, J.D.S. Exploring Claims and Marketing Techniques in Brazilian Food Labels. Br. Food J. 2019, 121, 1550-1564. [CrossRef]

103. Ahuja, J.K.C.; Li, Y.; Nickle, M.S.; Haytowitz, D.B.; Roseland, J.; Nguyen, Q.; Khan, M.; Wu, X.; Somanchi, M.; Williams, J.; et al. Comparison of Label and Laboratory Sodium Values in Popular Sodium-Contributing Foods in the United States. J. Acad. Nutr. Diet. 2019, 119, 293-300.e17. [CrossRef] [PubMed]

104. Samotyja, U. Influence of Shelf Life Labelling on the Sensory Acceptability of Potato Snacks. Br. Food J. 2015, 117, 222-233. [CrossRef]

105. Smith, V.; Clement, J.; Møgelvang-Hansen, P.; Sørensen, H.S. Assessing In-Store Food-to-Consumer Communication from a Fairness Perspective: An Integrated Approach. Fachsprache 2011, 33, 84-106. [CrossRef]

106. Leufkens, D. The Problem of Heterogeneity between Protected Geographical Indications: A Meta-Analysis. Br. Food J. 2018, 120, 2843-2856. [CrossRef]

107. Bui, M.; Kaltcheva, V.D.; Patino, A.C.; Leventhal, R. Front-of-Package Product Labels: Influences of Varying Nutritional Food Labels on Parental Decisions. J. Prod. Brand Manag. 2013, 22, 352-361. [CrossRef]

108. Kajale, D.B.; Becker, T.C. Determinants of Consumer Support for Mandatory Labeling of Genetically Modified Food in India: A Student Survey. Br. Food J. 2013, 115, 1597-1611. [CrossRef]

109. Odaman, T.A.; Bahar, R.; Şam, S.; Ilyasoğlu, H. Food Label Reading Habits of Health Sciences Students. Nutr. Food Sci. 2020, 50, 1021-1032. [CrossRef]

110. Choi, J.; Choi, A. Perceptions of Food Labelling about Allergens in Food Products in South Korea. Br. Food J. 2016, 118, $2842-2854$. [CrossRef]

111. Hajdú, N.; Lipták, K.; Săplăcan, Z. Comparative Analysis of Baby Food Labelling in Hungary and in Romania: Consumers' Perspective. Amfiteatru Econ. 2018, 20, 62-83. [CrossRef]

112. Hellier, E.; Tucker, M.; Newbold, L.; Edworthy, J.; Griffin, J.; Coulson, N. The Effects of Label Design Characteristics on Perceptions of Genetically Modified Food. J. Risk Res. 2012, 15, 533-545. [CrossRef]

113. Kimura, A.; Kuwazawa, S.; Wada, Y.; Kyutoku, Y.; Okamoto, M.; Yamaguchi, Y.; Masuda, T.; Dan, I. Conjoint Analysis on the Purchase Intent for Traditional Fermented Soy Product (Natto) among Japanese Housewives. J. Food Sci. 2011, 76, S217-S224. [CrossRef] [PubMed]

114. Connolly, C. In-line Quality Control of Product Coding from Cobalt IS. Sens. Rev. 2007, 27, 207-211. [CrossRef]

115. Marino, C.J.; Mahan, R.P. Configural Displays Can Improve Nutrition-Related Decisions: An Application of the Proximity Compatibility Principle. Hum. Factors J. Hum. Factors Ergon. Soc. 2005, 47, 121-130. [CrossRef] [PubMed]

116. Hess, J.M.; Slavin, J.L. Healthy Snacks: Using Nutrient Profiling to Evaluate the Nutrient-Density of Common Snacks in the United States: Nutrient Density of Snacks. J. Food Sci. 2017, 82, 2213-2220. [CrossRef]

117. Brierley, M.; Elliott, C. Transparent Choices: Communicating Packaged Food Content to Children. Vis. Commun. 2017, 16, 57-74. [CrossRef]

118. de-Magistris, T.; Gracia, A.; Barreiro-Hurle, J. Do Consumers Care about European Food Labels? An Empirical Evaluation Using Best-Worst Method. Br. Food J. 2017, 119, 2698-2711. [CrossRef]

119. Szlachciuk, J.; Ozimek, I. The Reliability, Use and Evaluation of Sources of Information on Foodstuffs. Br. Food J. 2017, 119, 442-452. [CrossRef]

120. Dixon, G.; McComas, K.; Besley, J.; Steinhardt, J. Transparency in the Food Aisle: The Influence of Procedural Justice on Views about Labeling GM Foods. J. Risk Res. 2016, 19, 1158-1171. [CrossRef]

121. Cucchiara, C.; Kwon, S.; Ha, S. Message Framing and Consumer Responses to Organic Seafood Labeling. Br. Food J. 2015, 117, 1547-1563. [CrossRef]

122. Kapsak, W.R.; Schmidt, D.; Childs, N.M.; Meunier, J.; White, C. Consumer Perceptions of Graded, Graphic and Text Label Presentations for Qualified Health Claims. Crit. Rev. Food Sci. Nutr. 2008, 48, 248-256. [CrossRef] 
123. Cummings, C.L.; Chuah, A.S.F.; Ho, S.S. Protection Motivation and Communication through Nanofood Labels: Improving Predictive Capabilities of Attitudes and Purchase Intentions toward Nanofoods. Sci. Technol. Hum. Values 2018, 43, 888-916. [CrossRef]

124. Nishida, W.; Fernandes, A.C.; Veiros, M.B.; Chica, D.A.G.; da Proença, R.P.C. A Comparison of Sodium Contents on Nutrition Information Labels of Foods with and without Nutrition Claims Marketed in Brazil. Br. Food J. 2016, 118, 1594-1609. [CrossRef]

125. de-Magistris, T.; Gracia, A. Consumers' Willingness to Pay for Light, Organic and PDO Cheese: An Experimental Auction Approach. Br. Food J. 2016, 118, 560-571. [CrossRef]

126. Chan, K.; Tse, T.; Tam, D.; Huang, A. Perception of Healthy and Unhealthy Food among Chinese Adolescents. Young Consum. 2016, 17, 32-45. [CrossRef]

127. Roberto, C.A.; Pomeranz, J.L.; Fisher, J.O. The Need for Public Policies to Promote Healthier Food Consumption: A Comment on Wansink and Chandon (2014). J. Consum. Psychol. 2014, 24, 438-445. [CrossRef]

128. Miller, L.M.S. Quantitative Information Processing of Nutrition Facts Panels. Br. Food J. 2014, 116, 1205-1219. [CrossRef]

129. Singla, M. Usage and Understanding of Food and Nutritional Labels among Indian Consumers. Br. Food J. 2010, 112, 83-92. [CrossRef]

130. Brandt, M.; Moss, J.; Ferguson, M. The 2006-2007 Food Label and Package Survey (FLAPS): Nutrition Labeling, Trans Fat Labeling. J. Food Compos. Anal. 2009, 22, S74-S77. [CrossRef]

131. Rousu, M.C.; Corrigan, J.R. Estimating the Welfare Loss to Consumers When Food Labels Do Not Adequately Inform: An Application to Fair Trade Certification. J. Agric. Food Ind. Organ. 2008, 6, 6. [CrossRef]

132. Butler, L.T.; Berry, D.C. Transfer Effects in Implicit Memory and Consumer Choice. Appl. Cogn. Psychol. 2001, 15, 587-601. [CrossRef]

133. Sapci, O.; Sapci, A. Consumer Perception of Food Expiration Labels: "Sell By" Versus “Expires On. " East. Econ. J. 2020, 46, 673-689. [CrossRef]

134. Muller, L.; Ruffieux, B. What Makes a Front-of-Pack Nutritional Labelling System Effective: The Impact of Key Design Components on Food Purchases. Nutrients 2020, 12, 2870. [CrossRef]

135. Escribano, M.; Gaspar, P.; Mesias, F.J. Creating Market Opportunities in Rural Areas through the Development of a Brand That Conveys Sustainable and Environmental Values. J. Rural Stud. 2020, 75, 206-215. [CrossRef]

136. Khandpur, N.; Rimm, E.B.; Moran, A.J. The Influence of the New US Nutrition Facts Label on Consumer Perceptions and Understanding of Added Sugars: A Randomized Controlled Experiment. J. Acad. Nutr. Diet. 2020, 120, 197-209. [CrossRef]

137. Zhan, J.; Ma, Y.; Deng, P.; Li, Y.; Xu, M.; Xiong, H. Designing Enhanced Labeling Information to Increase Consumer Willingness to Pay for Genetically Modified Foods. Br. Food J. 2020, 123, 405-418. [CrossRef]

138. Liang, A.R.-D.; Lim, W.-M. Why Do Consumers Buy Organic Food? Results from an S-O-R Model. Asia Prac. J. Mark. Logist. 2020, 33, 394-415. [CrossRef]

139. Nobrega, L.; Ares, G.; Deliza, R. Are Nutritional Warnings More Efficient than Claims in Shaping Consumers' Healthfulness Perception? Food Qual. Prefer. 2020, 79, 103749. [CrossRef]

140. Ferrari, L.; Baum, C.M.; Banterle, A.; De Steur, H. Attitude and Labelling Preferences towards Gene-Edited Food: A Consumer Study amongst Millennials and Generation Z. Br. Food J. 2020, 123, 1268-1286. [CrossRef]

141. Miller, A.C.; Polgreen, L.A.; Segre, E.M.; Polgreen, P.M. Variations in Marginal Taste Perception by Body Mass Index Classification: A Randomized Controlled Trial. J. Acad. Nutr. Diet. 2020, 120, 45-52. [CrossRef]

142. Zerbini, C.; Luceri, B.; Marchetti, A.; Di Dio, C. Shaping Consumption Propensity through the Emotional Response Evoked by Nutritional Labels: Evidence from an FMRI Study. Food Res. Int. 2019, 125, 108547. [CrossRef]

143. Bray, J.; Hartwell, H.; Price, S.; Viglia, G.; Kapuściński, G.; Appleton, K.; Saulais, L.; Perez-Cueto, F.J.A.; Mavridis, I. Food Information Presentation: Consumer Preferences When Eating Out. Br. Food J. 2019, 121, 1744-1762. [CrossRef]

144. Bailey, R.; Muldrow, A. Healthy Food Identification: Food Cues and Claims Affect Speeded and Thoughtful Evaluations of Food. Health Commun. 2019, 34, 735-746. [CrossRef] [PubMed]

145. Schnettler, B.; Ares, G.; Sepúlveda, N.; Bravo, S.; Villalobos, B.; Hueche, C.; Lobos, G. Are Consumers Willing to Pay More for Reformulated Processed Meat Products in the Context of the Implementation of Nutritional Warnings? Case Study with Frankfurters in Chile. Meat Sci. 2019, 152, 104-108. [CrossRef]

146. Berhaupt-Glickstein, A.; Hooker, N.H.; Hallman, W.K. Qualified Health Claim Language Affects Purchase Intentions for Green Tea Products in the United States. Nutrients 2019, 11, 921. [CrossRef]

147. Savchenko, O.M.; Kecinski, M.; Li, T.; Messer, K.D.; Xu, H. Fresh Foods Irrigated with Recycled Water: A Framed Field Experiment on Consumer Responses. Food Policy 2018, 80, 103-112. [CrossRef]

148. Mazocco, L.; Akutsu, R.C.C.A.; Botelho, R.B.A.; Da Silva, I.C.R.; Adjafre, R.; Zandonadi, R.P. Food Rating Scale in Food Services: From Development to Assessment of a Strategy for Consumer Healthier Choices. Nutrients 2018, 10, 1303. [CrossRef]

149. Shin, S.; van Dam, R.M.; Finkelstein, E.A. The Effect of Dynamic Food Labels with Real-Time Feedback on Diet Quality: Results from a Randomized Controlled Trial. Nutrients 2020, 12, 2158. [CrossRef]

150. Deliza, R.; de Alcantara, M.; Pereira, R.; Ares, G. How Do Different Warning Signs Compare with the Guideline Daily Amount and Traffic-Light System? Food Qual. Prefer. 2020, 80, 103821. [CrossRef]

151. Liu, P.; Wang, H.; Li, W.; Hu, B. The Influence of Sugar-Free Label Formats and Colors on Consumers' Acceptance of Sugar-Free Foods; Springer: Berlin/Heidelberg, Germany, 2020; Volume 1190, p. 626. ISBN 9783030498283. 
152. Zlatevska, N.; Chowdhury, R.M.M.I.; Tam, L.; Holden, S. Facts-up-Front: Should Food Companies Follow the FDA or Industry Label Format? The Effects of Combining Virtue and Vice Information on Consumer Evaluations. Mark. Lett. 2019, 30, 321-334. [CrossRef]

153. Mohajeri, M.; Hoojeghani, S.; Izadi, A.; Ghahremanzadeh, M.; Pourfarzi, F.; Nemati, A.; Barzegar, A. Food Choice Motivations among Ardabil-Iran Adults? Nutr. Food Sci. 2019, 50, 641-652. [CrossRef]

154. Miller, C.K.; Edwards, L.; Kissling, G.; Sanville, L. Evaluation of a Theory-Based Nutrition Intervention for Older Adults With Diabetes Mellitus. J. Am. Diet. Assoc. 2002, 102, 1069-1081. [CrossRef]

155. Przyrembel, H. Food Labelling Legislation in the EU and Consumers Information. Trends Food Sci. Technol. 2004, 15, 360-365. [CrossRef]

156. Office of the Chied Economist (OCE). How Much Food Waste Is There in the United States and Why Does It Matter; United States Department of Agriculture (USDA): Washington, DC, USA, 2020.

157. Patra, D.; Leisnham, P.T.; Tanui, C.K.; Pradhan, A.K. Evaluation of Global Research Trends in the Area of Food Waste Due to Date Labeling Using a Scientometrics Approach. Food Control 2020, 115, 107307. [CrossRef]

158. Wansink, B.; Chandon, P. Can “Low-Fat” Nutrition Labels Lead to Obesity? J. Mark. Res. 2006, 43, 605-617. [CrossRef]

159. Harris, J.L.; Pomeranz, J.L.; Lobstein, T.; Brownell, K.D. A Crisis in the Marketplace: How Food Marketing Contributes to Childhood Obesity and What Can Be Done. Annu. Rev. Public Health 2009, 30, 211-225. [CrossRef] [PubMed]

160. Kraak, V.I.; Gootman, J.A.; McGinnis, J.M. Food Marketing to Children and Youth: Threat or Opportunity? National Academies Press: Washington, DC, USA, 2006; ISBN 0-309-09713-4.

161. Blisard, N. Food Spending by US Households Grew Steadily in the 1990's. Food Rev. Nat. Food Rev. 2000, $23,18-22$.

162. Colby, S.E.; Johnson, L.; Scheett, A.; Hoverson, B. Nutrition Marketing on Food Labels. J. Nutr. Educ. Behav. 2010, 42, 92-98. [CrossRef]

163. Turra, C.; de Vian, C.E.F.; Nielsen, F.A.G.; Santos, P.S.; de Penteado, L.F.F. Overview of the Brazilian Citriculture Certification. J. Agric. Environ. Ethics 2014, 27, 663-679. [CrossRef] 